\title{
Analysis of Student Mathematical Problem-Solving Abilities in Graph Applications Learning Using the MEAs Approach
}

\author{
Nurlaili1 ${ }^{1, *}$ Utti Marina Rifanti ${ }^{2}$ Ridho Ananda ${ }^{3}$ \\ ${ }^{1,2}$ Faculty of Telecommunication and Electrical Engineering, Institut Teknologi Telkom Purwokerto, Jalan D.I. \\ Panjaitan 128, Purwokerto 53147, Indonesia \\ ${ }^{3}$ Faculty of Industrial Engineering and Design, Institut Teknologi Telkom Purwokerto, Jalan D.I. Panjaitan 128, \\ Purwokerto 53147, Indonesia \\ *Corresponding author. Email: nurlaili@ittelkom-pwt.ac.id
}

\begin{abstract}
Problem-solving abilities is one of the competencies that students must have. However, the level of student abilities to address problems related to real-life is still low. This study analyzes the students' mathematical problem-solving abilities after implementing learning using the MEAs approach in graph application. The research was conducted using a qualitative descriptive approach with the subject of S1 Telecommunication Engineering students. Data processing used triangulation in the form of data reduction, data exposure, and conclusions. Based on the study results, the research subjects had various levels of problem-solving abilities that divided into three categories: high about 34.5\%; moderate amounted to $27.6 \%$ and low at $37.9 \%$. Based on the analysis results, a student in the high category does not experience difficulties in fulfilling all indicators of problem-solving abilities. Most middle-category students experienced difficulties in looking back indicators, while a student in the low category did not meet the indicators well.
\end{abstract}

Keywords: Problem-Solving Ability, MEAs, Graph Application.

\section{INTRODUCTION}

Mathematics is an important branch of science that need to be studied at every level of education including in universities [1], [2]. Mathematics also has a very big role in the development of science and technology, including the field of information and communication technology [3], [2]. Developments in the fields of number theory, probability theory, linear algebra, analysis and discrete mathematics have been able to drive a rapid advance in information and communication technology [3]. Mastering knowledge in the field of mathematics is one of the graduate learning outcomes that telecommunication engineering graduates must strive to have because engineering abilities are closely related to mathematical knowledge. The relevance of basic mathematics is the reason for the drafting of several mathematics courses for the first-year students in the Telecommunication Engineering study program such as Linear Algebra, Discrete Mathematics, and Calculus. One example is the application of Discrete Mathematics in telecommunications learning. Based on the interviews with several lecturers who teach other subjects, an understanding of Discrete Mathematics studies such as graphs is essential in the process of learning data communication, traffic engineering, computer networks and programming. The strong interdependence between the topic of graphs and its applications on telecommunication network engineering is the basis for selecting this topic as a study material.

Problem-solving abilities as one of a crucial competency in learning mathematics [4], are a major concern at various levels of education including universities [5], [6]. Mastering problem-solving abilities improve student's abilities in using various mathematical ideas to determine solutions to a real problem [5]. Development of learning methods focused on improving problem-solving abilities is also needed in engineering learning, especially in telecommunications techniques.

The development of engineering work in the last two decades has been very fast, which encouraged professional engineer to be more efficient in their thinking and problem-solving abilities [7]. Also, problem-solving abilities are closely related to research 
in engineering work and the engineering education process [8]. The development of future engineering curriculum should be centered on competency development by focusing more on sharpening analytical abilities, design abilities, and problem-solving abilities [9]. According to Polya, indicators that can be used in measuring students' problem-solving abilities consist of 4 indicators, which is (a) Understand the problem, (b) Devise a plan, (c) Carry out the plan, (d) Look back [10], [11] meanwhile, NCTM mentions 4 indicators, which is (a) identify the known elements, questionable elements and their adequacy, (b) formulate the problem in a mathematical model, (c) interpret the results according to the problem, (d) use mathematics meaningfully [6].

Although problem-solving abilities is a fundamental competency for engineering students, the students' problem-solving abilities are still low. Based on the finding of researchers over the last few years, students' problem-solving abilities are still not optimal. Students have difficulty in modelling problems into mathematical form. This problem has also been found by several previous research. [1] stated that problem-solving abilities in mathematics are a very fundamental problem. The application of the auditory, intellectually, repetition (AIR) learning model is used by [1] to encourage the improvement of mathematical problem-solving abilities. [3] also expressed the same opinion that the level of problem-solving abilities is still low. This opinion is supported by the results of the 2012 PISA and TIMSS 2011. Hija implemented the group investigation learning method to support the improvement of problem-solving abilities. Research conducted by Putra [12] also shows that the problem-solving abilities of students at SMPN 1 Pulau Panggung are still low. Putra implemented contextual learning assisted hands-on activity model to improve students' problem-solving abilities. Putra's approach resulted in an improvement in students' problem-solving abilities. Based on research conducted by [13] on high school students, their problem-solving abilities still need an improvement because they experience difficulties and doesn't able to make a mathematical form from story case. Jumadi implemented the model-eliciting activities (MEAs) approach. Jumadi stated that learning with the MEAs approach can improve the problem-solving abilities of students. Jumadi's findings are also supported by [14] which states that the implementation of the MEAs approach results in improvement of problem-solving abilities by students even though not all indicators are achieved.

Based on the previous description, the improvement of student problem-solving abilities can be achieved by implementing certain learning models. One of the methods that can be used to improve students' mathematical problem-solving abilities is by using the Model Eliciting Activities (MEAs) approach. MEAs approach is a learning activity that uses a realistic approach that requires students not only to write down the results of a given problem but also to write down the process they do in solving the given problems. MEAs are expected to encourage students to form a mathematical model for solving a complex problem [15]. Several previous researchers have proven the MEAs approach is more effective in improving problem-solving abilities. The purpose of this study was to determine the level of student's problem-solving abilities after learning using the MEAs approach in the discussion of graph applications.

\section{METHOD}

This research uses a descriptive qualitative method to determine the problem-solving abilities of students after learning using the MEAs approach. Subjects in this study are 29 undergraduate students of Telecommunication Engineering in the second semester of 2019/2020 at the Telkom Purwokerto Institute of Technology (ITTP). The research instrument consisted of a test with questions for problem-solving abilities and interviews. The test is given to the students after they study using MEAs approach. The results of the test are grouped into three categories, which is high, medium and low. Based on those categories, three students were selected randomly from each category for interviews. This is done to obtain deeper information from their answers regarding the student problem-solving capabilities. Before the questions are given to students, they are validated by other lecturers who teaches discrete mathematics courses. The validation aims to see the suitability of the questions with the indicators and learning outcomes. Besides, it is also to see if there are still errors in language and writing.

The technique for data analysis was performed using data triangulation, which is data reduction, data presentation and conclusion drawing. In data reduction, an examination of student answers is carried out based on student problem-solving indicators. Furthermore, the data is presented based on the results of data analysis and interviews with students. The last step is to determine the conclusion from the previous step. Indicators of problemsolving skill used in this study are indicators of understanding the problem, indicators of preparing problem-solving plans, indicators of solving problems according to the plan and reviewing.

\section{RESULT AND DISCUSSION}

\subsection{Results}

This research was conducted on students of class $\mathrm{C}$ of telecommunication engineering by applying the MEAs approach to the learning process of the Graph application subject. At the end of the learning sessions, students are given a test to see their problem-solving abilities. The results of the student's answers were analyzed using problem-solving indicators. Based on the answers, the 
students' problem-solving abilities were grouped within the high, medium and low categories. The results of the answers grouping can be seen in Table 1. Next, we calculate the average percentage of right answer per indicator of problem-solving abilities. This is done to see which indicators are lacking for each high, medium and low category. The results of the percentage can be seen in Figure 1.

Table 1. Percentage of problem-solving abilities per category

\begin{tabular}{lc} 
Category & Percentage (in \%) \\
\hline High & 34,50 \\
Medium & 27,60 \\
Low & 37,90 \\
\hline
\end{tabular}
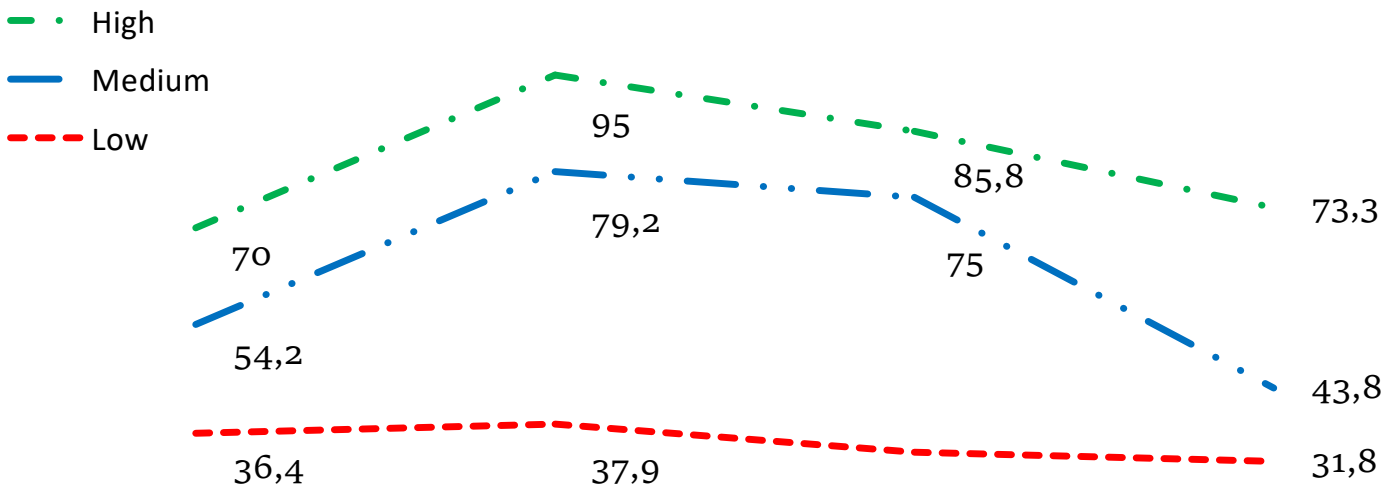

33,3

ID 1

ID 2

ID 3

ID 4

Figure 1 Percentage of problem-solving abilities achieved per indicator.

The indicator used in Figure 1 is ID $1=$ indicator of understand the problem, ID 2 = indicator of devise a plan, ID $3=$ indicator of carry out the plan and ID $4=$ look back. Based on Figure 1, it can be seen the percentage of achievement for each indicator of each category.

\subsection{Discussion}

Based on the grouping of problem-solving abilities in Table 1, three students were chosen to represent each category. The selected students were AAR for high category problem-solving abilities, NPP for the medium category, and APT for the low category. The selection is done randomly and then a deeper analysis of the three was carried out. The analysis results of the answers AAR indicated that in each question AAR able to meet the four indicators well. This can be seen in the first indicator, AAR able to understand the questions well so AAR can write down what he knows about the questions. In the second indicator, AAR able to design a solution plan to write a correct algorithm that will be used to determine the minimum spanning tree, and make the right graph on the graph colouring problem. Furthermore, by using the algorithm and graph, AAR can solve the problems that are asked. In the final stage, AAR also look back the answer by presenting the conclusions he obtained. According to the interviews, it was found that AAR had no difficulty in solving the given problem because he could understand the material well. Also, when doing exercises and assignment in MEAs learning process, AAR already accustomed to writing down the information from the questions, designing the solution to the questions, solving the problem, and look back the answer.

The next stage is the analysis of the NPP answers of the medium category. NPP are classified as students who have problem-solving abilities. This is based on the results of the NPP answer analysis, it is found that NPP has been able to meet the indicators of understanding the problem well enough where NPP able to write what asked by the questions. On the indicators of designing solutions, NPP has done well, where she able to make a correct graph and algorithm to determine the minimum span of tree problem and the shortest path. On the indicators of solving problems, NPP has written solutions based on tables, graphs and algorithms that have been written well even though there are some errors in the final results. NPP are not able to meet the fourth indicator, which is reviewing and checking the answers again. According to NPP interviews, it was found that in the learning process using MEAs approach, NPP able to understand the graph application very well. The difficulty NPP face on is she was not very thorough on the solving 
problem stage, that she makes an error on the final results. In addition, NPP also feels a little difficult to conduct re-examination of the answers, because she feels confusion to looking back the answers.

Lastly, an analysis of the low category answers, with student APT, was conducted. Based on the results of the analysis of the APT answers, it was found that each problem-solving indicator had not been fulfilled properly. On the indicators of understanding the problem, APT does not understand the problems given so they do not write down the information from the questions completely. On the indicators of designing solutions, APT did not draw graphs and also did not make tables that will help solve graph colouring problems and determine the minimum spanning tree. So, when solving problems, APT cannot solve the problems properly. APT also do not meet the indicator of looking back the answers. According to the interviews with APT, it was found that APT did not understand the graph application material well. This result in difficulties in using the algorithm that will be used to solve problems during the test and also confusion in drawing the graphs.

Overall, based on the analysis of the student answers, it was found that in the High category most students did not experience any difficulties in fulfilling all indicators, only a few students were still incomplete in writing information from questions and did not looking back the answers that had been made. In the Medium category students, some students are still incomplete in writing down the information from the questions. In addition, most of the students experienced difficulty in looking back their results. This can be seen after carrying out the plan, students continue to write the next question information. In low category, most students find it difficult to fulfil all indicators. This can be seen from the answers of the students where most of them did not write the information from question and some did write the information but it was not complete. Most of the students did not write a solution plan so there are errors when solving problems. Based on the results of the analysis, the MEAs approach can be used to improve the student's problem-solving abilities. However, improvements need to be made by increasing questions related to real problems and make students accustomed to solving problems using the four problem-solving indicators

\section{CONCLUSION}

Based on the results of this study, it was found that the student's problem-solving abilities in the high category were $34.50 \%$, the medium category was $27.60 \%$ and the low category was $37.90 \%$. From the analysis of student answers, it showed that High category students did not experience problems in fulfilling all problemsolving indicators. The Medium category students are experiencing a few obstacles in fulfilling the indicators to look back and review the answers that have been made.
Meanwhile, low category students have difficulty fulfilling every indicator of problem-solving abilities properly. The results of this study will be used as the basis for further research, which is developing teaching materials using the MEAs approach, so it can help to improve students' problem-solving abilities even better.

\section{ACKNOWLEDGMENT}

This article is the result of research with the Beginner Lecturer Research 2020 scheme using funds from the DRPM DIKTI. Therefore, the authors would like to thank DRPM DIKTI for their support and funding for the success of this research.

\section{REFERENCES}

[1] E. Agustiana, F. G. Putra, and L. Study, "Pengaruh Auditory, Intellectually, Repetition ( AIR) dengan Pendekatan Lesson Study terhadap Kemampuan Pemecahan Masalah Matematis," vol. 1, no. 1, pp. 1-6, 2018.

[2] R. W. Utami and D. U. Wutsqa, "Analisis Kemampuan Pemecahan Masalah Matematika dan Self-Efficacy Siswa SMP Negeri di Kabupaten Ciamis An Analysis of Mathematics Problemsolving Ability and Self-Efficacy Students of Junior High School in Ciamis Regency," vol. 4, no. 2, pp. 166-175, 2017.

[3] A. Hija, R. Nirawati, and N. C. Prihatiningtyas, "Pengaruh Model Pembelajaran Group Investigation (GI) Terhadap Kemampuan Pemecahan Masalah Matematis Siswa Pada Materi Peluang Kelas X MIPA,” 2016.

[4] N. E. W. Mook, "Chapter 1 Teaching Mathematics in the 21st Century," Princ. Stand. Sch. Math., vol. 1908, pp. 2-6, 2019.

[5] J. W. Darmani and A. Renaldi, "Analisis Kemampuan Pemecahan Masalah Matematis: Dampak Model Pembelajaran Reciprocal Teaching Dengan Fieldtrip," vol. 1, no. 3, pp. 373-380, 2018.

[6] D. D. Samo, "Kemampuan Pemecahan Masalah Mahasiswa Tahun Pertama pada Masalah Geometri Konteks Budaya Problem Solving Ability of First Year University Student in Cultural Context Geometry Problem," vol. 4, no. 2, pp. 141-152, 2017.

[7] I. Belski, "TRIZ course enhances thinking and problem solving abilities of engineering students," Procedia Eng., vol. 9, pp. 450-460, 2011.

[8] D. Missingham and J. Willison, "Student engineers optimising problem solving and research abilities," vol. 15 , no. 4, 2018. 
[9] S. A. Helmi, K. M. Yusof, S. Mohammad, M. S. Abu, and Z. Tasir, "Methods to Study Enhancement of Problem Solving Abilities in Engineering Students through Cooperative Problem-Based Learning," 2004.

[10] G. Polya, "How to solve it: a new aspect of mathematical method second edition," The Mathematical Gazette, vol. 30. p. 181, 1978.

[11] J. Adams et al., "Problem solving and creativity in engineering: conclusions of a three year project involving reusable learning objects and robots Problem solving and creativity in engineering: conclusions of a three year project involving reusable learning objects and," vol. 5, no. 2, 2010.

[12] F. G. Putra, "Eksperimentasi Pendekatan Kontekstual Berbantuan HoA terhadap Kemampuan Pemecahan Msalah Matematik,” pp. 73-80, 2017.
[13] Jumadi, "Penerapan Pendekatan Model-Eliciting Activities (MEAs) dalam Meningkatkan Kemampuan Pemecahan Masalah Siswa Kelas XII SMA N 2 Yogyakarta.," Aksioma, vol. 8, no. 2, pp. 43-49, 2017.

[14] H. Zulfitri, "Analisis kemampuan pemecahan masalah matematika setelah pembelajaran dengan pendekatan MEAs pada materi sistem persamaan linier tiga variabel," J. Gantang, vol. 4, no. 1, pp. 713, 2019.

[15] S. M. Chamberlin, S.A. and Moon, "ModelEliciting Activities as a Tool to Develop and Identify Creatively Gifted Mathematicians," J. Second. Gift. Educ., vol. 17, no. 1, pp. 37-47, 2005. 